\title{
A sport szerepe a napközi otthoni nevelésben
}

\section{Role of Sport in Afternoon School Activity (in Day Care Centers)}

\author{
Budainé Csepela Yvette, Borosán Lívia \\ Testnevelési Egyetem, Pedagógia és Módszertani Tanszék, Budapest
}

\begin{abstract}
Absztrakt: 2013 óta az iskolákban 16 óráig szükséges megszervezni az oktatást. Cél, hogy ez az iskolában töltött idő tartalmasan, igényesen teljen a gyermekek számára. Az egyik megoldás ennek érdekében a sportfoglalkozások szerepének megerősítése a délutáni tevékenységrendszerben. A mindennapos testnevelés megoldása a délutáni idósávban, a kollégák másoddiplomás testneveló tanár képzésének támogatása, az iskolai tantestület munkájának összehangolása, mind-mind megoldást jelenhetnek a tanulók mozgásszükségletének szakszerú, fejlesztő kielégítése érdekében. A napi min. egy óra időtartamú mozgás elengedhetetlen minden korosztály számára. Az általános iskolában a sokoldalú mozgásos tevékenységek fejlesztóleg hatnak a gyermekek testi, értelmi, pszichés fejlödésre egyaránt.
\end{abstract}

Kulcsszavak: sport, délutáni iskolai tevékenység, mozgásos fejlesztés

Abstract: Since 2013, schools have to organize education until 4 p.m. The aim is that children spend this time meaningfully. A solution could be to strengthen the role of sport classes in the afternoon activities. The afternoon (extracurricular) PE lessons, the postgraduate training of PE teachers, the coordination of the teachers work, etc, could all contribute to fulfil the demands of students for doing physical activities every day. One hour physical activity a day is essential for every age-group. Versatile motor activities in the elementary school affect children's physical, intellectual and psychological development as well.

Keywords: sport, afternoon school activity, motor development

\section{Bevezetés}

A gyermekek fejlődése szempontjából fontos, hogy az iskolában töltött egyre hosszabb idő tartalmasan és igényesen teljen. Ennek érdekében tanácsos a sportfoglalkozások szerepének megerősítése a délutáni tevékenységrendszerben.

-„Mit csináltatok ma az iskolában?”

- „Józsi bácsival kézilabdáztunk és fociztunk az udvaron - képzeld anya, ő is átöltözött és beállt játszani - olyan mókás volt, utána pedig „kidobósoztunk” a kistornateremben.”- hangzott el a fenti párbeszéd anya és harmadik osztályos lánya között.

A gyakorlati tapasztalat azonban azt mutatja, hogy nem minden általános iskolában történik meg ez a beszélgetés, mivel vagy a személyi vagy a tárgyi feltételek nem megfelelőek a délutáni sporttevékenység megvalósításához. A fent említett tanító bácsi a ritka kivételek közé tartozik -, abból a szempontból, hogy időt, energiát nem kímélve aktív sportolást végez maga is, illetve végeztet a tanítványaival.

„A sok mozgás a motoros képességek fejlesztése, a biológiai fejlődés és érés elősegítője is. A spontán szabad mozgások mellett fontos szempont az erre alkalmas testgyakorlatok körének szakszerű kiválasztása és a rendszeresség, azaz a mindennaposság." (Hamar, 2016a).

\section{A tények}

2013 szeptemberétől bevezették az általános iskolákban a délután négyig tartó tanítást, miszerint 16 óráig a gyerekeknek kötelező foglalkozásokon kell részt venniük az iskolákban. Ez alól a szülő kérhet írásban felmentést (A köznevelésröl szóló 2011. évi CXC. törvény Nkt. 55.S (1) bekezdése szerint) az 
intézményvezetőtől, aki saját hatáskörben rendelkezik a felmentés megadásáról (egyesületi sporttevékenység, zeneiskolai tevékenység, speciális iskolán kívüli fejlesztés, stb.)

A köznevelésről szóló 2011. évi CXC. törvény (Nkt.) szeptember 1-jétől hatályos 27.\$ (2) bekezdése szerint az általános iskolában 16 óráig foglalkozásokat, 17 óráig pedig felügyeletet kell biztosítani. A szintén szeptember 1-től hatályos 46.\$ (1) bekezdés a) pont szerint a tanulóknak kötelessége a 16 óráig szervezett egyéb foglalkozásokon részt venni. Az egyéb foglalkozás lehet napközi vagy tanulószoba is. Ezek a szabályok minden évfolyamra vonatkoznak (2011. évi CXC. törvény a nemzeti köznevelésröl).
Így azok a gyermekek, akik nem mennek el tanítás után valamilyen egyéb iskolán kívüli szervezett foglalkozásra, azok bizony 16.00-óráig az iskolában tartózkodnak. Ahhoz, hogy ez az idő tartalmas, fejlesztő és egyben rekreációs jellegű tevékenységgel teljen, ahhoz mind az iskola vezetésének, mind pedig a délutáni napközi otthoni foglalkozást vezető személynek erőfeszítést kell, kellene tennie.

\section{A rendelkezésre álló minőségi időkeret eloszlása}

A következőkben bemutatjuk, hogy mennyi az az időkeret, amellyel a délutáni időtartamban gazdálkodhatnak a pedagógusok (1. táblázat):

1. táblázat. A napköziben töltött idő évfolyamonként 1-4. osztályban (forrás: saját szerkesztés)

\begin{tabular}{|l|l|}
\hline 1. osztály: 12.00 -től 16.00/17.00 óráig & kb. 4-5 óra \\
\hline 2. osztály: 12.00/13.00-tól 16.00/17.00 óráig & kb. 4-5 óra \\
\hline 3. osztály: 13.00-tól 16.00/17.00 óráig & kb. 3-4 óra \\
\hline 4. osztály: 13.00/14.00-től 16.00/17.00 óráig & kb. 3-4 óra \\
\hline
\end{tabular}

A fenti idő áll tehát a napközis tanítók rendelkezésére, hogy a délutáni „menetrendet” tartalommal töltsék meg. Természetesen ez nem a „nettó” időkeretet jelenti, hiszen a tanulás időtartamára az egyes évfolyamokban a házi feladattól függően időt kell tervezni az alábbi módon:

A tanulás időtartama:

- 1. osztály: maximum 30-45 perc (marad min. 2-3 óra szabad időkeret, az ebédeltetést leszámítva).

- 2-4. osztály: maximum 45-60 perc (marad min. 2-3 óra szabad időkeret, az ebédeltetést leszámítva).

- 5-8. osztály: maximum 120 perc (marad min. 1 óra szabad időkeret, az ebédeltetést leszámítva). (2011. évi CXC. törvény a nemzeti köznevelésröl)

A fenti adatokból látható, hogy a szabad időkeret mennyisége jelentős aktív felhasználási lehetőséget nyújt a pedagógusok számára.

\section{Problémaforrások}

Sajnálatos módon hazánkban „nincsenek erre a nevelési színtérre vonatkozó kidolgozott országos, regionális és helyi fejlesztési koncepciók, cselekvési programok." (Füle, 2005). Minden egyes intézmény a pedagógiai programjában rögzíti azokat az irányelveket, melyek szerint a napközi otthoni nevelést megszervezi. Emellett a napközis nevelő év elején elkészíti a napközi otthoni nevelési tervet, melyben rögzíti az éves feladatokat, programokat, kirándulásokat az adott napközis csoportra kidolgozva.

Problémát jelenthet, ha vegyes csoportokban kell a pedagógusnak a délutáni foglalkozásokat vezetnie, hiszen az eltérő életkorú gyermekek fejlettségi szintje, érdeklődési köre, házi feladat mennyisége merőben más lehet, így ebben az esetben egy pedagógiai asszisztens segítsége megkönnyítheti a differenciált fejlesztést, képzést.

Az iskolai napközi otthonok nevelőmunkájának fejlesztése érdekében a Magyar Pedagógiai Társaság Napközi Otthoni Nevelési Szakosztálya még 2002 decemberében elkészítette „Az esélyteremtö napközi otthonok fejlesztése" című ajánlást, melyet az oktatási miniszterhez is eljuttattak. Ennek alapján a minisztériumban előterjesztés készült a napközi otthonok fejlesztési szükségleteiről. Sajnálatos, hogy az ajánlásban foglaltak - takarékossági okok miatt - nem valósulhattak meg (Ajánlás az Esélyteremtö napközi otthonok fejlesztése cimen, 2002).

A napközi otthoni részvétel nagyon sok szülő 
szemében egyenértékủ azzal, hogy a gyermekét biztonságban, felügyelet alatt tudja, amíg dolgozik és legalább a házi feladatok egy része elkészül, mire a gyermek hazaér a nap végére. Nos, ennél jóval többre lenne hivatott a délutáni foglalkozás. A délutáni tevékenységnek a családi nevelést kellene kiegészítenie, hiszen az iskola az a nevelési színtér, amely a család után a gyermekek életében igen jelentős szerepet játszik.

Külön figyelmet kellene szentelni az első osztályosok esetében mind a délelötti, mind pedig a délutáni tevékenység megszervezésére, hiszen az óvodából történő átmenetet egy barátságos légkörü, elfogadó, megértő, szerető környezet sokkal inkább segíti, mint csak a követelményeket állító, merev rendszerű, teljesítményorientált légkör. Ezek az első, iskolában töltött hónapok, évek múlva is meghatározó szereppel bírhatnak a személyiség fejlődésében, formálódásában, alakulásában.

Azt látni kell, hogy a napköziben folyó munka jelentős alkotórésze az iskolai tevékenység egészének, a nevelőmunkát egészíti ki. Szoros kapcsolatban kell lennie a délelőtti foglalkozásokkal, mintegy arra ráépülve, és kiegészülve a gyermekek életével.

\section{Egy követhető, jó példa}

Az alábbiakban a kaposvári Pécsi Utcai Tagiskola munkaközösségének napközit bemutató dokumentumából olvasható, hogy mitől lehet vonzó a napközi a gyermekeknek és szüleiknek:

- „szeretetteljes, elfogadó légkör megteremtése;

- integráció (egyéni foglalkozást igénylő tanulók);

- rugalmas napirend bevezetése;

- önálló tanuláskor felzárkóztatás, egyéni segítségnyújtás,

- tehetséggondozás;

- egészséges életmódra nevelés, higiéniás szokások kialakítása;

- környezeti nevelés;

- hasznos és kulturált szabadidő eltöltés." (http:// users.atw.hu/pecsiutisuli/index.)

A test és lélek harmonikus fejlesztése tekintetében így fogalmaz a dokumentum:

- „a mozgásigény kielégítése és a mozgáskultúra megalapozása (a tanulók naponta legalább 45 percet a levegőn tartózkodnak);

- a mozgáskoordináció, a hallás és a ritmusérzék fejlesztése;

- az egészséges életmód alapvető értékeinek a közvetítése;
- az érzelmi élet gazdagítása;

- az önismeret fejlesztésével, a reális önértékelés fejlesztése;

- a társas kapcsolatok igényének erősítése;..."

(http://users.atw.hu/pecsiutisuli/index.)

A fenti dokumentum is alátámasztja azt, hogy a napközi otthon tevékenység-rendszerében az eddigieknél lényegesen kiemeltebb szerepet kell kapnia az egészséges életmódra nevelésnek és a sportnak.

A személyi és környezethigiéniára, az étkezési kultúrára, az erkölcsi alapokon nyugvó (férfi és a nő közötti) szexuális nevelésre, a drogozás, az alkoholizálás, a dohányzás megelőzésére, prevenciójára és a sportolás szerepének tudatosítására hatékony terveket kellene készíteni.

\section{Az esélyegyenlőség biztosítása}

„2010-ig jó lenne elérni, hogy valamennyi napközi otthoni csoportban, naponként legalább harminc percben, az életkornak megfelelő játék- és sportfoglalkozásokat szervezzenek. [...] A középtávú fejlesztés során el kellene érni, hogy az esélytelenebb, szegényebb családok gyermekei is részesüljenek az említett foglalkozásokban." (Füle, 2005)

Nagyon gyakori, hogy számos programlehetőséget kínál az iskola a délutáni időszakban, azonban ezek nagy része önköltséges foglalkozás. A tehetősebb szülők gyermeke számára így lehetőség nyílik helyben, az iskolában a szakkörökön, sport vagy éppen zenei foglalkozásokon való részvételre, míg az anyagilag kedvezőtlenebb helyzetben lévő családok gyermekei az osztályteremben töltik a napjuk 90\%-át.

\section{A valóság}

Érdemes megemlíteni, hogy a mindennapos testnevelés bevezetése nem mindig jelenti 100\%ban a mindennapos testmozgás megvalósulását, hiszen a legkönnyebb a tanórai elmaradásokat, a pótlásokat, az egyes tanulmányi versenyekre való felkészítést a testnevelés óra rovására megszervezni. Így igen gyakran a heti 5 óra testmozgásból 2-3 marad a gyermekek számára.

Azt is gyakran hallani a testnevelö tanár kollégáktól, hogy a felső tagozatot elérve igen sok hiányosságot tapasztalnak a gyermekeknél az egyes sportági mozgások ismeretének tekintetében.

Gyakran nem kerül sor a kerettantervekben összeállított sportági gyakorlat elsajátíttatására. 
Ennek egyrészt személyi okai lehetnek, másrészt pedig a tornatermek, tornaszobák hiánya.

\section{Megoldási módok}

Minden pedagógus kollégának - a tanított tárgyától függetlenül - egy dologgal feltétlenül tisztában kellene lennie, mégpedig azzal, hogy a sport, "...a testnevelés pedagógiai szempontból nélkülözhetetlen szerepet tölt be. Egyedüli terület ugyanis, amely a tanulók egészséges testi fejlődését közvetlenül befolyásolja..." (Hamar, 2016b)

Kiváló megoldási mód lehetne, ha a délutáni időszakban a délelőtt elmaradt testnevelés órákat a napközis kolléga pótolná, például a tornateremben, így a tanulók mozgásigényének kielégítése is megvalósulhatna. Sajnos az iskolák mostoha anyagi körülményei miatt igen gyakran kényszerülnek a tornatermek bérbeadására, így az is előfordulhat, hogy a vadonatúj müfüves pályára nem is léphet rá az iskola tanulója, mondván nehogy „tönkre tegyék a gyerekek" a talajt, mert akkor a délutáni fizetős bérlő nem tudja azt igénybe venni.

Továbbá az egyes oktatástechnikai eszközöket is elérhetővé kellene tenni a délutáni időpontban is, nem elzárva, a tornaterem szertárában kellene „lapulniuk” a játékszereknek, már ahol van használatra alkalmas eszköztára az iskolának. Ennek megvalósítása csakis a tantestület tagjai közötti együttműködéssel lehetséges.

A helyhiányra kiváló megoldást mutatott be az interneten az ócsai Halászy Károly Általános Iskola pedagógusa, aki egy osztálytermi, közel 1,5 órás testnevelés órát tartott 3. osztályos tanulóknak. Ezzel prezentálva azt, hogy tantermi körülmények között is - egy kis kreativitással, ötletes megoldásokkal - meg lehet mozgatni akár 30 tanulót is (https:// www.youtube.com/watch? $v=Q Q \operatorname{ar} 82 z 6 B O 0)$. A másik példa a Csík Ferenc Általános Iskola és Gimnázium tanárának, Leitner Józsefnek a bemutató testnevelés órája tanteremben ( $h t t p s: / / w w w . y o u t u b e$. com/watch? $v=k T z D u 41 s o X s)$.

Mivel a sport a „szervezett szabadidős tevékenységek" között kap helyet a napközi otthoni nevelésben, ezért a cél többek között:

- az életkori sajátosságokhoz alkalmazkodó mozgás- és játékigény kielégítése az egészséges életmód elveinek figyelembevételével;

- a pozitív személyiség tulajdonságok (akarat, kitartás, fegyelmezettség, tolerancia, segítőkészség, kreativitás stb.) fejlesztése;
- a közösségi összetartozás érzése és tudata mellett, az egyéni képesség, ügyesség optimális kibontakoztatása;

„A játék mint megoldásmód tehát motiváló hatású, gyermekszerü és életszerü keretbe helyezve a mozgást, vonzóvá teszi azt a gyermek számára, s így szinte észrevétlenül erősíti a mozgás iránti szükségletet." (Bábosik, 2016)

A délutáni sporttevékenység néhány megoldási módja lehet a napközis pedagógus vezetésével például:

- ügyességi játékok eszközökkel és a nélkül,

- labdajátékok, bajnokságok keretében is,

- mozgásos- és körjátékok,

- küzdő játékok,

- futó- és fogójátékok,

- váltó- és sorversenyek,

- akadályversenyek,

- zenés-táncos mozgásos tevékenységek (néptánc, modern tánc, zumba, stb.).

( http://docplayer.hu/1641248-Napkozisfoglalkozasi-terv-vazlata.html)

A játék megszervezése, kiválasztása során mindig szem előtt kell tartanunk, hogy eközben fejlődik a gyermekek:

- érzelmi élete;

- társas kapcsolatai;

- szabálytudata;

- önfegyelme;

- értelmi képessége;

- pszichikus funkciói, melyek a tanulás esetében rendkívül fontos szerepet játszanak.

„A játék a tevékenységben való részvételre, öntevékenységre ösztönöz, aktivizál, és szervező ereje van." (Borosán, 2016) A szervezett délutáni foglalkozások során kivitelezhető lenne a fiú-lány bontás is az alsó tagozatban - ami a délelőtti testnevelés órán nem használatos - a párhuzamos napközis csoportokban, hiszen harmadik, negyedik osztályban a gyermekek érdeklődési köre alakulóban van.

Elképzelhető tehát, hogy amíg a lányok zenéstáncos tevékenységen, ritmikus gimnasztika vagy akár aerobik foglalkozáson vesznek részt, addig a fiúk labdarúgással, kézilabdával vagy éppen küzdősporttal foglalkoznak.

Iránymutatónak tartjuk az SZTE JGYTF Gyakorló Általános és Alapfokú Művészeti Iskola napközi otthoni munkaközösségének projekttervét, amelyben a napközis játéktevékenységek feladatát az alábbiakban összegzik: 


\section{"Játéktevékenységek:}

- Az időjárásnak megfelelő szabadtéri és tantermi játékok tervezése, szervezése.

- Az egészséges életmódnak megfelelő, az életkorból adódó mozgásigény kielégítése, a mozgáskultúra fejlesztése.

- A közös játék örömének megélése, átélése.

- Az erkölcsi, jellembeli és akarati tulajdonságok, az önirányítás és önfegyelem fejlesztése.

- A kulturált közös játék megvalósítása, az ezzel kapcsolatos közösségi szokások kialakítása.

- Az értelmi képességek játéktevékenység során történő fejlesztése.

- A játék gyermekekre való komplex hatásának, a testi és lelki regenerálódásnak a biztosítása.

- Az alkotó fantázia, a kreatív képesség fejlesztése, játékvariációk alkalmazása.

- A gyorsaság, ügyesség, erő, kitartás fejlesztése.

- A játék szabadságának, az önállóság élményének biztosítása a gyermekek számára.

- A különböző, sokféle játékon keresztül a tanulók egyéni képességének, tehetségének a kibontakoztatása, önismeretre nevelés, az önbizalom erősítése.

- Az igényes, mozgásos szabadidő eltöltési szokások megismertetése, annak alkalmazására buzdítás.

- A játékok szabályainak megismertetése, a szabályok szükségességének beláttatása, az azokhoz való alkalmazkodás gyakoroltatása.

- Ismerkedés a különböző játékszerekkel, sporteszközökkel, használatuk megtanulása, gyakorlása...

- Futó- és fogójátékok megismertetése, elsajátíttatása, játszása. A gyors mozgás, az irányváltoztatás, a helyes futótechnika fejlesztése.

- Ügyességi, mozgáskoordinációs, egyensúlyérzéket fejlesztő feladatok, gyakorlatok végrehajtása.

- Sor és váltóversenyek szervezése. Az egymásra figyelés és az összhangban végzett csapatmunka fontosságának tudatosítása, az együttes siker megélése, a helyes versenyszellem kialakítása.

- Különböző népek játékainak megismertetése, játszása. Az eltérő kultúrából adódó különbségek felfedeztetése.

- Mozgás improvizációk zenére. A zene átélése, harmonikus mozgás, az érzelmek mozdulatokon, különböző mozgásokon keresztül való kifejezése.

- Tánctanulás. A táncok szerepének, sokszínűségének, önkifejezési lehetőségeinek tudatosítása. Az életkornak megfelelően néhány népi és társastánc alaplépéseinek az elsajátíttatása, egyszerű tánckoreográfiák betanítása. A zenei hallás, a dalkultúra, a ritmusérzék, a koordinált mozgás fejlesztése.

- Sportversenyek szervezése. Napközis csoportok közötti, évfolyamszintű vetélkedések. A különböző feladatok végrehajtásában való együttes sikerélmény átélése, kortárs csoportokkal való összehasonlítási lehetőség, megmérettetés, versenyhelyzetek megélése.'

(Az Oktatásért Közalapitvány Közoktatási Alkuratórium pályázata KözOKA II.)

\section{Megbeszélés}

Vajon a megvalósítást, a megvalósulást a gyakorlatban a pedagógusok, illetve az iskola részéről hogyan lehetne kivitelezni? Erre a feltett kérdésre a válaszunk a következő:

\section{a.) Egyéni képzés, önképzés útján}

Ebben az esetben joggal kérdezhetjük, hogy mi a motivációja a tanítónak. Miért fordítson külön időt, energiát arra, hogy a foglalkozások megszervezésével, megtervezésével „bajlódjon”.

\section{b.) Szervezett - támogatott továbbképzések}

Akár a Testnevelési Egyetem Felnőttképzési Csoportjának szervezésében, akár kihelyezett formában (döntően a sportjátékok és a testnevelési játékok témakörben, az életkori jellegzetességeket figyelembe véve).

\section{c.) Másoddiplomás képzés}

Örvendetes tény, hogy a 2017/18-as tanév szeptemberétől a Testnevelési Egyetem meghirdeti, a rövid ciklusú tanárképzés keretén belül, a tanítói diplomával rendelkező pedagógusok számára a 4 féléves testnevelő tanárképzést.

Ez kiváló lehetőség arra, hogy a magukban affinitást érző kollégák szakmailag is felkészültté válhassanak a testnevelés oktatására, és ezzel akár a napközis foglalkozások keretében is szakképzett oktatók foglalkozhassanak a gyermekekkel.

$\mathrm{Az}$ általános iskolai testnevelő tanári diploma birtokában pedig a 8. osztályig is bekapcsolódhatnak a testnevelés oktatásába, ami a mindennapos testnevelés bevezetésével felmerülő testnevelő tanári hiányra adhat hosszú távú megoldást. 


\section{Irodalom}

1. Ajánlás az Esélyteremtö napközi otthonok fejlesztése címen. 2002. december 16. Összeállitotta: Füle Sándor és munkatársai. www.epa.hu

2. Az Oktatásért Közalapítvány Közoktatási Alkuratórium pályázata KözOKA II. Az iskola, ahol szeretnek a tanulók napközibe járni SZABADIDŐS FOGLALKOZÁSOK MEGVALÓSÍTÁSA PROJEKTEKBEN Készítette: Az SZTE JGYTF Gyakorló Általános és Alapfokú Művészeti Iskola napközi otthoni munkaközössége 2006, Szeged http://docplayer.hu/2025076-Szabadidosfoglalkozasok-megvalositasa-projektekben. html (Letöltés: 2016. 12. 28. )

3. Bábosik Zoltán (2016): A mozgás szerepe a szociális életképesség megalapozásában. In: Hamar Pál (szerk.). A mozgás mint személyiségfejlesztő tényező. Eötvös József Könyvkiadó, Budapest. 65-76.

4. Borosán Lívia (2016): A szabadidő mint a személyiségfejlesztés egyik lehetséges eszköze. In: Hamar Pál (szerk.). A mozgás mint személyiségfejlesztö tényező. Eötvös József Könyvkiadó, Budapest. 53-64.
5. Füle Sándor (2005): Az iskolai napközi otthoni nevelőmunka fejlesztése. Új Pedagógiai Szemle, 55(5): 85-93.

6. Hamar Pál (2016a): A testnevelés tantervelmélete. Eötvös József Könyvkiadó, Budapest.

7. Hamar Pál (2016b): Terminológiai gondolatok tantervelméletről és testnevelésről. In: Hamar Pál (szerk.). A mozgás mint személyiségfejlesztō tényező. Eötvös József Könyvkiadó, Budapest. 13-25.

8. 2011. évi CXC. törvény a nemzeti köznevelésröl. Magyar Közlöny, 2011. 162. szám, 39622-39695.

9. http://users.atw.hu/pecsiutisuli/index. php?option $=$ com_content $\&$ task $=$ view $\&$ id $=1$ 6\&Itemid=40 (Letöltés: 2016.12 .27$.

10. h t t p s:// w w w. you tube.com/ watch? $\mathrm{v}=\mathrm{QQ}$ ar $82 \mathrm{z} 6 \mathrm{BO} 0$

11. h t t p s://www.youtube.com/ watch? $\mathrm{v}=\mathrm{kTzDu} 41$ soXs

12. http://docplayer.hu/1641248-Napkozisfoglalkozasi-terv-vazlata.html (Letöltés: 2017. 01. 02.) 